IRSH 60 (201 5), Special Issue, pp. 63-94 doi:I0. I017/So0208590 I 5000486

(C) 2015 Internationaal Instituut voor Sociale Geschiedenis

\title{
Locals and Migrants in the Coalmining Town of Enugu (Nigeria): Worker Protest and Urban Identity, \\ I9I $5-1929$
}

\author{
CAROLYN A. BROWN \\ Department of History, Rutgers, The State University of New Jersey \\ I6 Seminary Place, New Brunswick, NJ o890I, USA
}

E-mail: cbrown@panix.com

\begin{abstract}
Aвstract: This article focuses on the varied workforce in and around the Enugu Government Colliery, located in south-eastern Nigeria and owned by the British colonial state. Opened in I9I 5 at Udi and in I9I7 at Iva Valley and Obwetti, the mines were in a region with a long history of slave raids, population shifts, colonization, and ensuing changes in local forms of political organization. The mines brought together an eclectic mixture of forced and voluntary unskilled labor, prisoners, unskilled contract workers, and voluntary clerical workers and artisans. Moreover, the men were from different ethno-linguistic groups. By taking into account this complex background, the article describes the gradual process by which this group of inexperienced coalminers used industrial-protest strategies that reflected their habituation to the colonial workplace. They organized strikes against the village men, who, as supervisors, exploited them in the coalmines. Their ability to reach beyond their "traditional" rural identities as "peasants" to attack the kinsmen who exploited them indicates the extent to which the complex urban and industrial environment challenged indigenous identities based on locality as well as rural status systems and gender ideologies. One of the major divisions to overcome was the one between supposedly backward "locals", men who came from villages close to the mine, and more experienced "foreigners" coming from more distant areas in Nigeria: the work experience as "coalmen" led "locals" to see themselves as "modern men" too, and to position themselves in opposition to authoritarian village leaders. The article thus traces the contours of the challenges confronting a new working class as it experimented with unfamiliar forms of affiliation, trust, and association with people with whom it shared new, industrial experiences. It investigates the many ways that "local" men maneuvered against the authoritarian control of chiefs, forced labor, and workplace exploitation by "native" and expatriate staff.
\end{abstract}

As I look back on these early days of our struggles to obtain a dignified and rightful place for our African workers, I think [...] that the ig2os were critical for us. It was during this period that Nigerian workers began to understand what it meant to be an inferior, to be subject to the "busts" and the "booms" of Western 
capitalist manipulations. While the suffering of our workers was great, they learned to stand on their own feet. They expressed themselves by means of strikes and unrest which the British did not appreciate. More important than the strikes were the expressions of fraternal interest in workers elsewhere. We did not have an effective trade union organization in the I920s, but we had a lot of Nigerian workers who thought and acted like trade unionists.

Michael Imoudu, President of the Nigerian Railway Workers' Union ${ }^{\mathrm{I}}$

In the summer of 1926 miners in eastern Nigeria, a remote outpost of the British Empire, demonstrated their "fraternal interest in workers elsewhere" by going on strike during the British General Strike in which the militant British coalminers had played a leading role. In mid-May the Colonial Office had asked the colliery to expand its operations to compensate for the loss of British coal used to bunker ships along the coast. The manager hired more workers, added a shift, and prepared to increase production. In July the "local" day laborers - tub, rail, and timber - walked off their jobs, demanding a I-penny increase to raise their wages to I shilling and 3 pence per day. The strike was short - from I 2-I4 July - but successful, because it occurred during a period of high labor demand because of the British General Strike, and was especially significant because it was the first time the inexperienced "local" workers used a conventional form of industrial protest rather than deserting the mines and returning to their farms, as they had until this point. They understood that, although they were not skilled miners, without their tubs the hewers (miners) could not produce, and without their timber no new work faces could be opened, nor roadways reinforced. Moreover, they also recognized the administrative hierarchy of the state by refusing to meet with the local magistrate and insisted on meeting personally with the Resident of Onitsha Province.

The relationship between this consciousness and position in the workforce would be demonstrated in the next decade, when these same "unskilled" workers eloquently explained why their wage demands were reasonable. What was especially remarkable is that now the "locals" were showing the industrial sophistication of the more savvy "foreigners" - skilled men from more distant areas, who had been trained by missionaries and worked in capitalist workplaces where they cultivated a tradition of bothersome militancy.

This was the Enugu Government Colliery, an enterprise owned by the colonial state, which opened in south-eastern Nigeria in I9I 5 . It was the only colliery in West Africa and was considered a vital resource during the world wars. Its coal had strategic value as the main fuel for the Nigerian Government Railway, the steamships that plied the coast, and, during World War II, the convoys and railways of Britain's West African colonies and their allies.

I. Personal communication, 24 June 1964, to Peter C.W. Gutkind, as cited in The Emergent African Urban Proletariat, Occasional Paper Series, No. 8, Centre for Developing-Area Studies, McGill University (Montreal, I974), p. 7 (my italics). 
When the colliery began production in 1915 , the workforce was an eclectic mixture of forced and voluntary unskilled labor, prisoners, unskilled contract workers, and voluntary clerical workers and artisans. Moreover, the men were of different ethnic groups. The skilled artisans and clerks were either Yoruba, from western Nigeria, or Igbo, from more "civilized" and colonized areas of south-eastern Nigeria. This heterogeneous mixture of men with differing skills, under different systems of labor control, with differential commitments to wage labor, and familiarity with the capitalist workplace, created eclectic forms of protest and work cultures.

Although the workforce rarely exceeded 2,000 in the early decades and 7,000 later on, its power lay in its location in the West African political economy and attracted the concern of the highest levels of Britain's Colonial Office. The mines and the Nigerian Railway were "sister" state enterprises, and until I 937 both were administered by the Director of the Nigerian Railway. The railway was also the colliery's main consumer and transporter, creating a functional integration that linked the two industries' workers in protest. When the railway workers struck, coal could not be evacuated from the mines. When the mineworkers struck, the railway lacked the coal to run. The coal workers had little experience in wage labor and benefitted from the militancy of the railway workers from western Nigeria, who had worked on the western branch of the railway since its opening in the I 890 . In an export economy like Nigeria, workers in transport (i.e. railways, docks, etc.) and fuel production were in a key position. They were often the first labor sector to recognize their own power and to exert it. ${ }^{2}$

The discovery of coal some 135 miles from the Niger Delta led to the construction of a railway line to carry that coal to the coast. Railway construction took several years and did not reach the colliery until May i9i6. Both industries used forced labor to introduce a "free labor market" that officials claimed signified the superiority of British "civilization" over the "primitive" slave-holding societies of eastern Nigeria. But despite the fact that "free labor" was promoted as a modernizing force, most of the workers were anything but "free". The labor market was actually a byproduct of the conquest.

This article describes the gradual process by which a group of inexperienced African coalminers in south-eastern Nigeria used industrial-protest strategies that reflected their habituation to the colonial workplace. Eventually, they organized strikes against the senior village men, who, as supervisors, exploited

2. After World War II a rash of general strikes ran through Africa. Timothy Oberst notes that many were led by transport workers; Timothy Oberst, "Transport Workers, Strikes and the 'Imperial Response': Africa and the Post World War II Conjuncture”, African Studies Review, 3 I (I 988), pp. I I 7-I 33. On the importance of transport workers in late colonialism in different world regions, see also several of the contributions in Stefano Bellucci, Larissa Rosa Corrêa, Jan-Georg Deutsch, and Chitra Joshi (eds), "Labour in Transport: Histories from the Global South, c.17501950", Special Issue 22, International Review of Social History, 59 (2014). 
them in the coalmines. Their ability to reach beyond their "traditional" rural identities as "peasants" to attack the kinsmen who exploited them indicated the extent to which the complex urban and industrial environment challenged indigenous identities based on locality, rural status systems, and gender ideologies. This forced some of the young men to be open to new forms of affiliation that were more appropriate to their new workplace and experiences as migrants in the city of Enugu. As they interacted with "foreign" men in the workplace and in the city, these young migrants used multiple, intersecting, and contradictory identities as bases of personal construction. Their senior rural leaders were confused and resentful of the challenges posed by these young men to the existing social and generational hierarchies, and tried to undermine industrial actions against the mines.

The article traces, too, the tortuous struggle of young migrant workers to reconcile rural social identities, rooted in regionalism and kinship, with their class position as labor in a despotic colonial industry. Because the colliery opened during the final phase of the conquest, it encountered problems in securing labor for the coalmines and the railway. Most of the workers and inhabitants of Enugu were Igbo, the largest ethnic group in south-eastern Nigeria, but the majority of the skilled workers and urban inhabitants were from more distant areas in south-eastern Nigeria. While government classified them as Igbo, to the local people they were "foreigners", because they spoke a different dialect, had a strange religion Christianity - and were trained in sophisticated, modern skills that allowed them to hold the best jobs in the industry and in the town.

Additionally, the city also had a small group of skilled workers and clerks who were Yoruba, the largest group in western Nigeria. They had also been trained by missionaries and were employed as artisans on the railway and as clerks in the city. Finally, there was one other group, called the "Saro", a cosmopolitan African people descended from slaves who had been liberated from slave ships after Britain abolished the slave trade in $\mathrm{I} 807$ and who were quite familiar with Western culture, British rule, and Christianity. To the "locals" they were all "foreigners", and they resented the imposition of a city of "strangers" on their land. These divisions between "locals" and "foreigners", as well as additional divisions among the "locals", became a barrier to solidarity, so needed in colonial industry. And these conflicts were exploited by government and "traditional" rulers, both of whom recognized in them a mechanism to control workers.

This study focuses on the first fourteen years of the Enugu Government Colliery, I915-1929, when the industry introduced wage labor to rural communities in south-eastern Nigeria. The colonial state, motivated by early twentieth-century notions of "civilization" and racial hierarchy, organized local governance on the basis of erroneous assumptions about the structure of power in African villages. In a system called "indirect rule", it incorporated local "men of prominence" in the government project and 
imbued them with extraordinary powers that violated the most basic traditions of political power in local villages. Supposedly based on "native authorities", this system imposed colonial "chiefs", most of whom were former slave dealers, on all communities. Their brief was the daily and detailed operations of the unlawful and brutal state. Much of the power of the "chiefs" concerned the question of labor - supplying the thousands of workers needed by a state operating where no labor market existed. But their influence reached into colonial industries affecting the deployment of labor, systems of worker control, and industrial relations practices.

Connections between the coalmines' "native" staff and "chiefs" usually personal and close, thereby projecting industrial discipline into the rural villages, and in turn bringing rural systems of control into the workplace. The colliery manager encouraged this intervention by assuming a limited managerial style that mirrored the "indirect rule" practices being used to stabilize rural villages. The industry relied on the "boss boys" to handle workers' complaints, ignoring the fact that they themselves were the causes of most complaints.

Rural identities were powerful bases of personal affinity (and continue to be so even today). Even in the most cosmopolitan of African cities, men considered their natal villages to be their real "homes". It was in these villages that they expressed political power, attained prestige, exercised authority, and established gendered status. However, despite the power of rural affiliations for both local and foreign young men, those who worked in the coalmines and/or lived in the colonial city were more open to experimenting with new associations involving unfamiliar people who were considered "foreigners". The junior men who became coalminers and/or migrated to Enugu found in the city a particularly rich and dynamic environment, filled with new freedoms and opportunities for new forms of masculine invention. Additionally, subordinate men - the poor, slaves, and the young - discovered new opportunities to challenge the systems of oppression controlled by senior men in the villages. In this way wage labor and urbanization exacerbated the intergenerational conflicts between older men and their juniors and undermined rural systems of legitimacy and authority. ${ }^{4}$

There were some six strikes from January I9I9 to early I 92 I, followed by a second wave in I924-1 925 , and a final crisis in I 929. The protests by "foreign" clerks, artisans, and "pick boys" or miners in 1917, 1918, and 1919 had been

3. Despite the problematic character of the notion, "chief" is used without quotation marks hereafter.

4. One of the most serious points of contention concerned access to young fertile women as wives. In many cases senior men used both their power to restrict the younger men's ability to marry and their influence with the elder men of the young women's families to negotiate for their marriages. For a discussion of this tension see Lisa Lindsay and Stephen Miescher, "Introduction", in idem (eds), Men and Masculinities in Modern Africa (Portsmouth, NH, 2003), pp. I-30, I-9. 
successful in securing pay increases to meet wartime inflation. But at that time the "locals" protested by deserting, returning to their farms and villages. However, the protests of the I920s, the focus of this article, were more tenacious and widespread. Most importantly they were led by "locals", categories of labor heretofore uninvolved. These strikes established a "culture of protest" that characterized the industrial environment of the coal industry throughout its subsequent existence. The recurrent character of these industrial actions, the use of accepted forms of worker protest, the assumptions that workers made about the social responsibilities of the state, and their manipulation of the policy dissonance among state actors indicates a qualitative change in the consciousness of the workers. They operated from a position that as workers they deserved to live and work under certain conditions, and they wanted the state to secure these conditions on their behalf.

The emergence of "local" workers as the leadership of mine protest indicates the willingness of young men to trust new forms of alliances that they associated with "modernity" and "progress". As their income made its imprint on the development of local villages, they became "coalmen", associated with the transformation to a new world. As working men and urban migrants from the adjacent area formed alliances and relationships with other people from outside their natal villages, their senior rural leaders were confused by the influence that "foreigners" had over their men. To the workers this confusion became yet another indicator of the rural leaders' backwardness and inability to understand the new industrial realities.

Now these young men could utilize elements of the new political and economic system for personal improvement, especially to accelerate the attainment of male maturity. The early history of the "coal city" of Enugu thus exhibits not only the characteristic conflicts between "locals" and "foreigners", but also those arising from challenges posed by young men to the existing social and generational hierarchies.

\section{THE PEOPLE OF SOUTH-EASTERN NIGERIA}

The city of Enugu and the mines were located some 135 miles from the Bight of Biafra coast in the northernmost region of south-eastern Nigeria, called Igboland. This was an area occupied by the Igbo people, one of the three largest ethno-linguistic groups in contemporary Nigeria. Most labor for the coalmines and railroad was recruited from their villages. The Igbo lived in an area of some I 5,800 square miles framed on the west by the Niger River (with some settlement on the western bank of the Niger River), the Benue to the north, the Cross Rivers to the east, and the Niger Delta to the south. The Delta was on the Bight of Biafra, and the hinterland sometimes carries that same name.

5. This is the origin of "Biafra", the name of the breakaway region during the Nigerian Civil War (1967-1970). Enugu was the capital of this brief state. The literature on Biafra is extensive, but one 
The Igbo are the largest group in south-eastern Nigeria. They and most of the other numerous ethno-linguistic groups in the area - Ibibio, Efik, Ogonni - had a similar socio-political organization of small autonomous village-groups, or clusters of villages, without chiefs. ${ }^{6}$ Important political decisions were made by a series of overlapping associations and groups (male councils of elders, women's associations, age grades, associations of "native" doctors, etc.), each with specific responsibilities. The council of senior/elder men and some women, whose opinions were respected, included representatives of constituent villages. But no representative had the authority to make decisions without consulting the group. All the people in a compound, village, or village-group believed that they were descendants of a common ancestor whose several offspring established constituent villages of a "village-group" or "town". The whole system functioned gerontocratically: the oldest man in a compound, the oldest compound in a village, and the oldest village in a village-group had special authority and sacred power, though none could function autocratically. This all began to change during the trans-Atlantic slave trade and was transformed radically during colonial rule.

In Igbo villages power was especially diffuse since most villages had neither strong chiefs nor kings. ${ }^{7}$ However, these were not villages of equality. By the nineteenth century a new class of wealthy slaving merchants, Ogaranyan, had forced a strengthening of authority based on wealth at the expense of seniority. Many Ogaranyan were involved in the internal slave trade, which expanded with the decline of the trans-Atlantic trade by the late nineteenth century. These savvy traders proved very skillful in hiding their activities and ingratiating themselves with the British invaders in 1900.8 Aware of global economic trends, they were quick to supply services to the colonial soldiers. In return, officials assumed that they

of the best histories of this tragic event is Axel Harneit-Sievers, Jones O. Ahazuem, and Sidney Emezue, A Social History of the Nigerian Civil War: Perspectives from Below (Münster, 1997), and fictionalized by the remarkable young Igbo/American writer Chimamanda Ngozi Adichie in Half of a Yellow Sun (New York, 2007).

6. A village-group was a cluster of villages established by the descendants of a common ancestor. Thus kinship to the common ancestor became the central element of social cohesion of the group. 7. The exception is Onitsha, which was influenced by the Kingdom of Benin near the Niger River; Richard N. Henderson, The King in Every Man: Evolutionary Trends in Onitsha Ibo Society and Culture (New Haven, CT, 1972).

8. These men were surprisingly "modern". By World War I they were so familiar with British culture that early missionaries, upon visiting one in his remote home, found a Morris Minor parked in the yard, despite the fact that roads were quite primitive. They were especially astute at using "Western" commodities as prestige goods to secure clients and symbolize modernity. For a contemporary account of this encounter see Northwestern University Africana Library, Church Missionary Society Records, Microfilm Reel 204, Box G3.A3/0 191 3-I6 "Niger Mission", The Rev. Basden, "Report on a Visit to the Udi District", n.d. The records can be found in the Herskovits Library Collections, Northwestern University. The original documents are at SOAS, University of London. 
were chiefs (despite there being no chiefs in pre-colonial Igbo villages). These were the men who would also supply drafted labor to the coalmines and infrastructural projects. ${ }^{9}$

The political fragmentation of Igboland as reflected in regional "ethnic" identities was related to the diverse ecology. ${ }^{\circ}$ Igboland is located in the Guinea coastal climatic area, a region with a wide range of rainfall. Within this broad region are several micro-ecological zones with varying soil types, rainfall, and vegetation. As was the case throughout West Africa, communities based in the thick rainforests tended to be small and fragmented, while large, multi-ethnic states were clustered in the savannah region, where horses could become the crucial technology of empire building. ${ }^{\text {I }}$ Although the Igbo shared some dialects and other cultural traits before the conquest, they never perceived themselves as one distinct "people", and they had historically organized their ever-shifting political alliances on a sharply defined regionalism. The key regional distinction was the "coast" versus the "interior".

"Coastal" society came to have a distinct meaning denoting groups who, by the twentieth century, had had some 400 years of contact with Europe, a contact that was reflected in their names, mercantile skill, and receptivity to European culture. ${ }^{\mathrm{I} 2}$ From the sixteenth century the coastal communities had come into closer contact with European traders, missionaries, and the precursors to colonial officials, and over time these regional identities had become more defined, reflecting differential levels of familiarity with European culture, labor systems, and the colonial economy. This familiarity

9. For a history of one such "big man" see Dillibe Onyeama, Chief Onyeama: A Story of an African God (Enugu, 1982).

I0. I deliberately do not use the term "tribe" for a number of reasons, including its implication of primordialism and social stasis. Africanists have generally rejected this term because it has become clear that so-called tribal identity was constructed, is usually related to colonialism, and is not a useful category of analysis. For this debate see Archie Mafeje, "The Ideology of 'Tribalism", Journal of Modern African Studies, 9 (197I), pp. 253-26I; Leroy Vail (ed.), The Creation of Tribalism in Southern Africa (Berkeley, CA, 1989). For a discussion regarding the Igbo, see Douglas A. Anthony, Poison and Medicine: Ethnicity, Power, and Violence in a Nigerian City, I966 to 1986 (Portsmouth, NH, 2002).

I I. This was the case with the Yoruba, who had been part of the Oyo Empire, a state created around I I 00 and patrolled by a powerful cavalry. For a discussion of the relationship between ecology and political structure see Akin Mabogunje, "The Land and Peoples of West Africa", in Jacob F.A. Ajayi and Michael Crowder (eds), History of West Africa, I (New York, 1970), pp. I-32.

I 2. The adoption of European names indicated the hybridity of these communities. Examples include the names of some traders, such as the Robin Johns, a prominent trading family, or Antera Duke. Coastal communities adopted elements of European culture as early as the sixteenth century. This included dress, housing styles (later even a kind of prefabricated Victorian house), and Christianity. On the Robin Johns see Randy Sparks, The Two Princes of Calabar: An Eighteenth-Century Atlantic Odyssey (Cambridge, MA, 2004); on Antera Duke see Stephen D. Behrendt, A.J.H. Latham, and David Northrup, The Diary of Antera Duke: An EighteenthCentury African Trader (Oxford, 2012). 
with Western culture was also to become a major influence on how workers engaged with the coal industry and the city.

\section{THE IMPACT OF THE SLAVE TRADE}

The most significant factor contributing to the divisive regional identities among the mine workforce was the region's role in the trans-Atlantic slave trade. Between the late eighteenth and mid-nineteenth centuries over I.2 million (20 per cent) of the slaves crossing the Atlantic came from southeastern Nigeria, and most were Igbo. ${ }^{13}$ The internal trade continued into the nineteenth century, when slaving turned particularly violent as the Biafran hinterland became a palm oil producing area. ${ }^{14}$ In a paradoxical way, the "legitimate" trade in palm products actually increased the demand for unfree labor in the palm belt.

The British conquest of Northern Igboland, the area of the subsequent Enugu colliery, incorporated the Udi district, a remote, impoverished area of relatively disadvantaged villages in comparison with groups from the coast. Moreover, Udi was still suffering from the after-effects of centuries of slave trading: Udi people had been a primary source for the Atlantic slave trade and were sold by middlemen to coastal traders. This association with slavery left an indelible mark upon the way they were viewed by other Igbo communities. Igbo from the more "civilized" areas of the south-eastern region - Onitsha, Owerri, Calabar - disparaged the people of Udi as being particularly "backward", "primitive", and "degraded", both because of their enslavement and because of their poverty. They called them "Wa Wa", a pejorative term meaning "primitive backward people". They had a reputation for kidnapping, lawlessness, and incessant warfare related to defense systems villages employed to prevent enslavement. They were the last group to be converted to Christianity and consequently lacked the skills to fill the most lucrative jobs that opened up in Enugu, and the skilled posts in the mines and railway.

In the late nineteenth century the destructive impact of the internal slave trade directed to the palm belt reached catastrophic proportions. Wealthy bandit traders, called Awagwu, created their own settlements of multiple wives, free dependents, and slaves, which they ruled with impunity. These marauding bandits operated totally outside the customary traditions of

13. The calculations of the trade from this area are undergoing constant revision owing to the major data projects that followed the Slave Voyages project directed by David Eltis (see www. slavevoyages.org), a multinational research effort that has allowed scholars to build, collaboratively, a more accurate quantitative estimate of slaves exported. See also Carolyn A. Brown and Paul E. Lovejoy (eds), Repercussions of the Atlantic Slave Trade: The Interior of the Bight of Biafra and the African Diaspora (Trenton, NJ, 201 I).

14. One of the best discussions of this shift as well as of the internal political and social transformation is David Northrup, Trade Without Rulers: Pre-Colonial Economic Development in South-Eastern Nigeria (Oxford, 1978). 


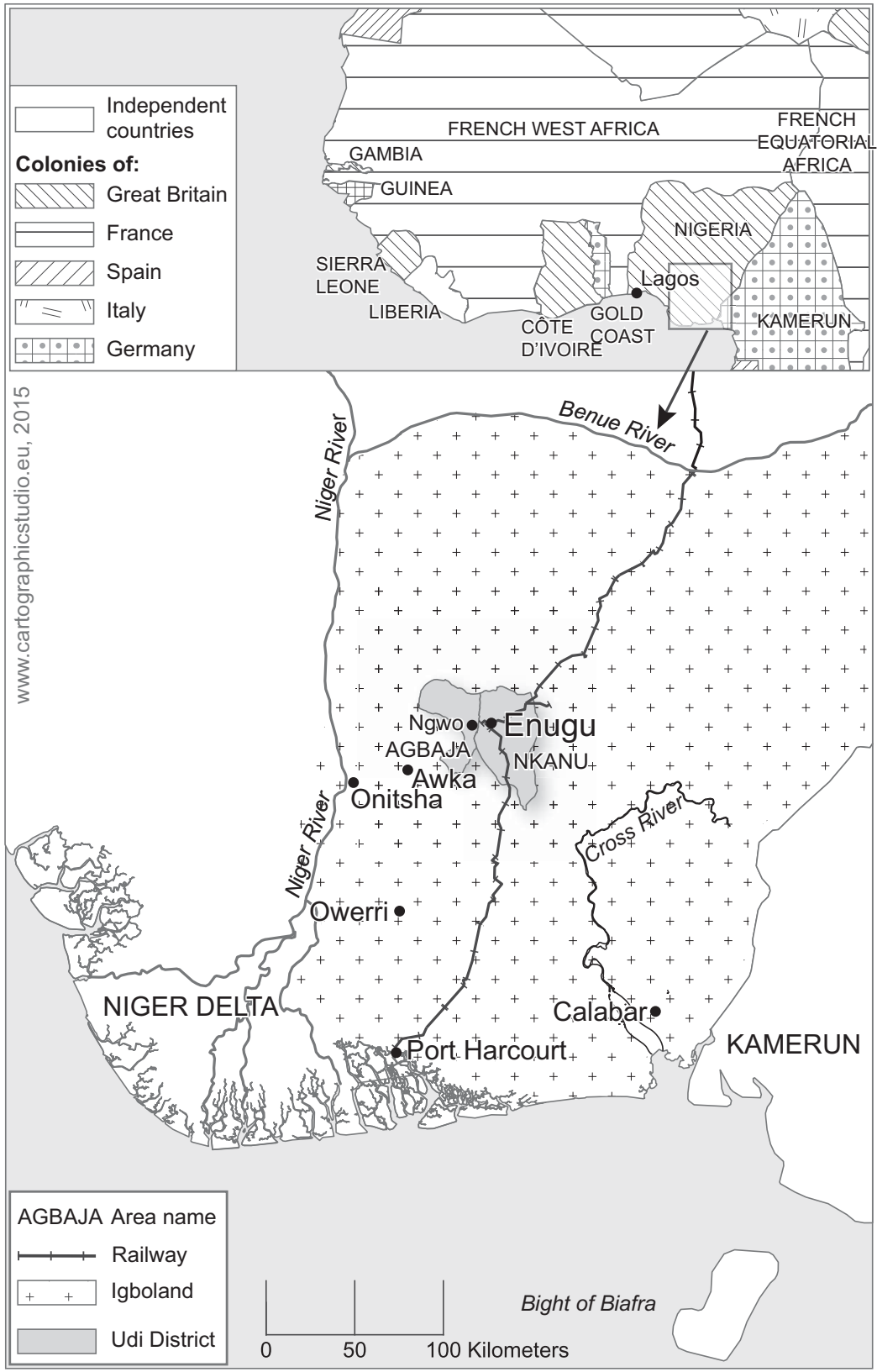

Figure I. Map of the Niger Delta. 
rural politics. They formed private militias, which they dispatched to raid villages and kidnap and sell adults and children, largely to the palmproducing areas near Owerri. This violence fundamentally changed both the governing system and the social stability of the region. The imprint was reflected in the architecture of the area, where watchtowers, maze-like compound entrances, and compact settlements became rural survival strategies. These bandits were particularly active in the area between Onitsha and Udi, where they destroyed villages, sending desperate refugees to areas like the Udi escarpment, a barren range of sandy hills to the west of the city of Enugu. Some of the prominent men who collaborated with the British invasion were from this group of Awagwu. ${ }^{\text {Is }}$

As the global trade - initially the slave trade, later the palm trade increasingly infiltrated village economies, wealthy merchants contested the political/ritual power of the elders and forced some accommodations to allow their wealth to translate into political power. The resulting Ogaranyan model of elite masculinity entailed heading a "big compound", an exaggerated polygamous household of many wives, ${ }^{16}$ children, clients, and slaves, and being engaged in the conspicuous consumption of foreign commodities (i.e. bicycles, cars, Western clothes). Elite men tied to the mercantile economy differed significantly from those senior men who were "household heads" and whose status came from their ability to sustain and defend their household, to maintain personal autonomy, to avenge insult or violence, and to demonstrate commitment to the betterment of the corporate group. ${ }^{17}$ In addition, the model of the Ogaranyan tied elite masculinity to the world market in ways that popularized gender relations based on substantial wealth. The Ogaranyan wore special clothes, danced exclusive dances, belonged to expensive associations, and were buried with considerable ceremony and expense. ${ }^{\mathrm{I}}{ }^{8}$

By the late nineteenth century elite masculinity impacted upon the aspirations of many men in a new way. The "big men" had transformed their wealth into political and spiritual power using prestigious "title"

I 5. The most prominent Udi trader, Onyeama Onwusi, became the most powerful of this group. See G. Ugo Nwokeji, The Slave Trade and Culture in the Bight of Biafra: An African Society in the Atlantic World (Cambridge [etc.], 2010).

16. See Jeff Guy, "Analysing Pre-Capitalist Societies in Southern Africa", Journal of Southern African Studies, I4 (1987), pp. 18-37. In the Udi area one chief was known for having eighty wives. The symbolism of this "conspicuous exhibitionism" was not lost on less wealthy men, and this form of elite masculinity became one of the models other men aspired to adopt.

17. For a discussion of this more "normal" male honor see Carolyn A. Brown, "A 'Man' in the Village is a 'Boy' in the Workplace: Colonial Racism, Worker Militance, and Igbo Notions of Masculinity in the Nigerian Coal Industry, 1930-1945”, in Lindsay and Miescher, Men and Masculinities, pp. I 56-I74.

18. Ifi Amadiume, Male Daughters, Female Husbands: Gender and Sex in an African Society (London, I987), p. 3 I. 
societies, the most prominent being the Ozo title. ${ }^{19}$ Before colonialism, few men could hope to attain the model of elite masculinity of the Ogaranyan, but regular wages opened this possibility to aspirants, especially as it offered an alternative way to marry, a prerequisite for mature adulthood. In fact, the state pulled into its new economy those young men who had not actually attained mature adulthood. Their conscription into wage labor by the Ogaranyan chiefs paradoxically empowered young men to challenge the power of their seniors in the village - in this way, the chiefs actually created their own nemesis. In fact, as we will see below, the workplace and the city of Enugu became incubators of an anti-chief/elder men sentiment, articulated largely by the Westernized elite and actively supported by young men.

The Udi district had been the northernmost wing of the supply system for the slave trade. The slave trade, however, was experienced differently by the two major Udi groups, the Agbaja and the Nkanu, called "clans" by anthropologists. ${ }^{20}$ While the Agbaja became slaves, the Nkanu collaborated with slave traders. In the late eighteenth through the nineteenth century marauding militias pushed hundreds of refugees to the Udi escarpment, where they formed densely populated settlements. By 1900 the land was so infertile that it was virtually useless for farming. ${ }^{21}$ In these villages, called the Agbaja, lived "locals" who would eventually supply the majority of the mines' labor force. But in the opening years of the mines, they would resist recruitment. However, this was unsustainable given the inability of young men to establish farms on the overcrowded escarpment. This was especially serious because farming was a precondition for young men to marry, establish their lineage, and form their own compounds and households, a prerequisite for social maturity.

19. Title societies were ranked associations in which entrance and ascent in rank depended on payment of an increasing level of fees. In the I 920 s membership required a feast, followed one year later by $£_{20}$ pounds in cash, 100 fowls, another feast, and payment to a person to perform facial scarification; P. Amaury Talbot, The Peoples of Southern Nigeria (London, 1969), III, p. 775.

20. The designation of "clan" was an example of the invention of categories to classify Igbo communities. It is characteristic of a particular form of "colonial knowledge" that was generated in the I920s. See Dmitri van den Bersselaar, "Acknowledging Knowledge: Dissemination and Reception of Expertise in Colonial Africa”, History in Africa, 33 (2006), pp. 389-393; also idem, "Missionary Knowledge and the State in Colonial Nigeria: On How G. T. Basden Became an Expert", History in Africa, 33 (2006), pp. 433-450; A.E. Afigbo, "Anthropology and Colonial Administration in South-Eastern Nigeria, I89I-1939", Journal of the Historical Society of Nigeria, 8 (1975), pp. 19-35.

21. In addition to land scarcity the escarpment suffered from severe erosion, which made migration a necessity to grow food. See David Grossman, "Migratory Tenant Farming in Northern Iboland in Relation to Resource Use" (Ph.D. dissertation, Columbia University, New York, 1968). 
Marriage was an overwhelming preoccupation for young men, desperate to establish their independence and to take their place among the senior men in their village. While an older son in an extended family could look forward to inheriting the compound and land of the father, ${ }^{22}$ the younger sons would have to forge their own way, colonizing new areas to establish their independence, found their own lineages, and establish farms. Fulfillment of the imperative to migrate from one's father/parents is reflected in the founding narrative of most Igbo village-groups. ${ }^{23}$ In 1900 Agbaja's young men, thwarted in securing their own farming lands, were in a crisis. They were forced to migrate to the adjacent fertile plains of their neighbors, the Nkanu, who were the local middlemen selling slaves to the coast. Thus Agbaja men depended on access to land owned by the very people who had sold, and continued to sell, their people as slaves. ${ }^{24}$ But Agbaja carried an even more humiliating burden: the more "civilized" Igbo of Owerri and Onitsha accused them of being so depraved as to violate sacred moral codes and sell some of their own children into slavery. It appears, however, that this was a tragic choice that they had to make to secure food to support the remaining family members. ${ }^{25}$ The sale of kin was considered an ultimate indicator of social degradation.

Unlike the refugee communities of Agbaja, Nkanu settlements were on the adjacent fertile plains to which they dispatched slave families. As is the case in many slave-trading communities, by the nineteenth century Nkanu came to retain large numbers of slaves, locally called $\mathrm{Obu}$, who performed tasks judged "beneath" the status of the Amadi, the freeborn men. This gave Nkanu a particularly rigid and persistent form of slavery which defied British efforts, though indeed quite tepid, to end slavery and discrimination against descendants of slaves throughout the colonial period. ${ }^{26}$ One consequence of the incorporation of slaves in freeborn villages was a series of very large segregated Obu villages from which the Amadi

22. There was no land alienation. Extended families were given compound land and farmlands by the village council of men. But in the Agbaja area land shortage prevented all but the eldest sons from acquiring access to their fathers' land.

23. See the Intelligence Report for a number of "clans": Nigerian National Archives, Enugu [hereafter, NNAE], CSE I/85/6 I I 4, H.J.S. Clark, Assistant District Officer, "Intelligence Report on the Ngwo Clan of Abaja Area, Udi Division, Onitsha Province".

24. Reuben Kendrick Udo, "The Migrant Tenant Farmer of Eastern Nigeria", Africa, 34 (1964), pp. 326-339.

25. W.R.G. Horton, "The Obu System of Slavery in a Northern Ibo Village-Group”, Africa, 24 (1954), pp. 3I I-336.

26. The ending of colonial slavery has been the subject of many studies in the last twenty years. We now know that in this area, as throughout the British colonies, the "Indian model" of colonial slave policy was employed. This involved criminalizing the sale of slaves and leaving it to the slaves to "free" themselves. Should owners try to resist, the colonial government would not use the courts to enforce their rights. 
seized men to work on the railroad and later in the coalmines. While it is difficult to say exactly when slavery ceased to exist, ${ }^{27}$ we do know that wage labor and the cash economy substantially eroded its moorings after World War I. ${ }^{28}$

The experience of Mazi Anyionovo Nwodo, an Obu coalminer, illustrates the gradual transformation from slave to worker. His account refers to the i920s:

I and Edenwede Ogbu of Isigwe were pace setters sort of, to the Ihus or Obias. ${ }^{29}$ We were the first set of people to enlist personally to the Europeans without the consent of the chief for their personal betterment. [...] I was among those sent by the chief to work in the construction of the railway line from Otakpa, now in Imo State. Otakpa was where the Nkanu people under Chief Chukwuani of Ozalla joined in the railway construction. [...] All payment for those that were sent out by the chief, whether on the coalmine or railway construction, was directed to the chief. We were left with nothing, but at a later date the chief started giving us small amounts of what each of us realized. This was after we had realized from the Europeans that we were paid for the job we had been doing for long. Because of the chief's action we deemed it unnecessary not to be obligatory to the chief. ${ }^{30}$ In the circumstance, we started looking for our own greener pastures for personally paid jobs and the most possible area to look for jobs was in Enugu. ${ }^{3 \mathrm{P}}$

Anyionovo Nwodo had escaped a system in which his "owner" attempted to profit from the agricultural labor he performed for him, as well to claim part of the wages he earned for paid colliery work. ${ }^{32}$

27. Slavery has proven to be an especially resilient form of coercive labor in the Nigerian context, which can easily be folded into family structures or marriage. For a discussion of the systems of disguise of actual slavery in the early colonial period (some of which continue today) see Robin Chapdelaine, "A History of Child Trafficking in Southeastern Nigeria, I900s-I930s" (Ph.D. dissertation, Rutgers University, NJ, 20I4).

28. For a discussion of the complicated meaning of "freedom" in the Enugu area, see Carolyn A. Brown, "Testing the Boundaries of Marginality: Twentieth-Century Slavery and Emancipation Struggles in Nkanu, Northern Igboland, 1920-29", Journal of African History, 37 (1996), pp. $5 \mathrm{I}-8 \mathrm{O}$.

29. Ihu is another term used for slave in this area. Obias has a different history: the term means "stranger" and its use was a product of a period of violent struggle by the slave villages to force the state to outlaw the use of $\mathrm{Ihu}$ or $\mathrm{Obu}$, which clearly meant slave. I discuss this in Brown, "Testing the Boundaries".

30. This is Nigerian English.

31. Interview with Mazi Anyionovo Nwodo, Uhuona, Ugbawka, I8 August 1988. Interview conducted in Igbo. The translation into Nigerian English was made by the unidentified interviewer.

32. In some respects this resembled the "hiring out" system used during the nineteenth century in the US South, especially as slavery waned. Owners would allow their slaves to move to the city or off the plantation and perform labor for a wage. They were then required to pay their owner a percentage of their earnings, in something like "rent", for the freedom to earn a wage. See Richard C. Wade, Slavery in the Cities: The South, I820-I 860 (New York, 1964). 
This was a violation of the customary exploitation - "moral economy" of slavery, ${ }^{33}$ in which slaves could work a certain number of days on fields allocated to them and represented an intensification of exploitation for the $\mathrm{Obu}$ men. As the Amadi tried to seize income the Obu earned in wage labor, they sparked a revolt in many slave villages, especially in that of Anyionovo Nwodo. His village, Isigwe, was physically distant from that of their owners, which gave them an opportunity to experience daily autonomy over their internal affairs, a process that encouraged solidarity and a collective consciousness. In I 922 the people of Isigwe were in the forefront of the insurrection when the Obu from Nkanu finally rose up against their owners' claim on their wages.

Tensions continued to build up as earnings from coalmining emboldened the $\mathrm{Obu}$ to demand social equality with the Amadi. Incomprehensible to the British, they fought most hard to protect their families from kidnapping and sale, to retain their wages, to have full access to land (without the conditionality of slave labor), and the right to join the same types of prestigious male associations that distinguished the most prominent $A$ madi. The Amadi were enraged, and seized and sold several Obu children. The Obu, in turn, expelled the Amadi from their segregated village. ${ }^{34}$ The conflict continued for most of the decade until the state brokered an agreement for land to establish separate $\mathrm{Obu}$ villages, but they were never accepted as equals of the Amadi. ${ }^{35}$

The history of enslavement was humiliating to the Agbaja men and appeared to be but one additional attribute of their "backward" and "immoral" culture. Additionally, they were unfamiliar with the cultures, technologies, and religions of the more "civilized" areas. This disparity became even more intolerable from the late nineteenth century when they interacted with the more modern "foreigners", ironically in a city - Enugu - built on the land of the marginal Agbaja villages. The British had unwittingly built a modern industry and city on the foundation of the nineteenth-century economy slavery - that had instilled terror, dislocation, and internal discrimination in the self-same area. As colonial rule took root, it intensified the pre-existing regional disparities between the prosperous slave-dealing (and later palmtrading) coastal trading states and the poor hinterland areas, like Udi, ravaged

33. Slaves (and their families) worked on their owners' fields a certain number of days per week and the rest of the time they could work on fields designated for their own use. By charging them part of their wages, Amadi violated their right to the product of their labor during their own time. 34. There is a detailed discussion of the revolt, which erupted in 1920 and continued with increased intensity until 1922, when the area was in civil war. For a discussion of Obu men demanding full equality and social acceptance (a demand which the freeborn community never conceded), see Brown, "Testing the Boundaries".

35. When I conducted interviews in this area, freeborn descendants quickly noted that any prestigious associations established by the descendants of $\mathrm{Obu}$ were invalid and fraudulent. 
by slaving. This was the difference between the "local" population (and workers) and the "foreigners", i.e. those who had come from regions further away, like Onitsha and Owerri, to fulfill jobs. ${ }^{36}$ To the people of Udi, Enugu was "their town".

\section{THE INVENTION OF CHIEFS AND THE CREATION OF NEO-TRADITIONAL LABOR SYSTEMS}

The northern area of south-eastern Nigeria was the last region to be incorporated into the Nigerian colony. While Britain's conquest of southeastern Nigeria began in 1900 , the invasion did not reach Udi, the future area of the coalmines, until 1904, and even then the conquest proved ephemeral as annual military expeditions occurred for four years. Resistance did not end in 1908, however, when initial hostilities concluded. Even then, despite the overwhelming military superiority of the troops it took a decade before the area could be considered "pacified" (in I9I4). In the midst of the conquest, officials set the political reconstruction in place; "indirect rule", as it was called, established chiefs' courts to adjudicate disputes, levy fines, and to conscript labor.

In 1914 Frederick Lugard became Governor General of Nigeria and centralized more power in the hands of the chiefs. ${ }^{37}$ This increased the burden on the people of a partnership of despotism between an outlaw state and the local collaborators that it recognized. For those so anointed, the tasks of governing were lucrative but formidable and risky, for despite the military superiority of the state, Europeans were too few on the ground when villagers decided to end, once and for all, a chief's despotic rule. While bludgeoned into submission in the "pacification" of the region, the local people were forced, in defeat, to become "free laborers" for a myriad of colonial projects. This occurred in the first year of the war.

The Enugu Government Colliery opened in I9 I 5 under military guard and defeated villages were forced to supply labor in retribution for their resistance. But the Udi villages rose up again - in an event called "the Udi business" triggered by the government deployment of colonial troops to the eastern border with German Kamerun. The desperate shortage of coal reserves forced the Colonial Office to open the colliery despite this unsettled context and the financial constraints of the war. Supplies of Welsh coal, the favored source, were far from secure, given hostilities. Since local labor was up in arms, officials

36. For the history of these two areas see Adiele E. Afigbo, "Southeastern Nigeria in the I9th Century", in Jacob F.A. Ajayi and Michael Crowder (eds), History of West Africa, II (London, I987, 2nd edn), pp. 429-484.

37. For a discussion of the Lugardian reforms see Carolyn A. Brown, "We Were All Slaves": African Miners, Culture, and Resistance at the Enugu Government Colliery (Portsmouth, NH, 2003), pp. 80-84. 
recruited workers from Onitsha, a large market town on the Niger River, and later from Owerri, an important commercial center in the palm belt to the south nearer the coast. Colonial chiefs became labor recruiters and young men and slaves were the usual target.

Colonial rule was more established in Onitsha and Owerri, and their men, while from the same ethnic group - Igbo - as Enugu's "locals", were far more habituated to wage labor, even in its conscripted form. In addition to these groups of Igbo men there were men from other areas of Nigeria. Railway workers, skilled artisans, and clerks came to the city from the distant cosmopolitan Yoruba city of Lagos in the west (370 miles away). Christianized Yoruba and "Saro", descendants of slaves captured from ships that violated Britain's I 807 abolition of the slave trade, became the city's "foreign" elite. To the local communities, the men from Onitsha, Owerri, and Lagos were "foreigners" who occupied their land and farms, and monopolized the highest paying jobs in "their" city of Enugu. Thus, from the very beginning, the colliery workforce had a "local-foreigner" division that challenged the development of a solidarity the workplace otherwise encouraged.

Workers were paradoxically empowered by the inferior quality of Enugu coal, which was sub-bituminous "soft" coal that broke easily, disintegrating with each handling into ever smaller - and less usable - chunks. It was also prone to spontaneous combustion, a dangerous attribute given the wooden railway wagons that transported coal to the coast. Despite these limitations, Udi was a large, secure regional source of coal when war jeopardized the sea lanes that brought the superior Welsh coal. Because of its fragility and combustibility, purchasers intentionally held small reserves, a practice that made the market especially vulnerable to work stoppages. Miners grew to recognize this strategic advantage, and although they were relatively inexperienced and isolated on the "fringes of empire", Enugu coal workers quickly reflected the activist image of British miners that so menaced Britain's energy source. Enugu miners similarly leveraged the power that their inferior product gave them in the regional transport system. They used this knowledge skillfully to create an industrial tradition of troublesome militancy that gave them a national reputation as a strategically powerful sector of Nigeria's working class. They organized frequent work stoppages, manipulated state officials, and selected as leaders men capable of defending their interests as workers. These patterns would be visible in the first locally led strikes in the $1920 .^{38}$

The complexity and fluidity of Igbo political systems (colonially perceived as "anarchic" and "chaotic") frustrated both early government officials and anthropologists who were creating "colonial knowledge" to and militant leaders among the corps of men being trained in the "Nigerianization" initiative. 
develop working instruments of local government. They invented categories - such as "tribe" - to refer to virtually every corporate settlement of several lineages. They could not reach a consensus on whether the Igbo were "one tribe" or dozens of "sub-tribes", each with its own ethnographic profile. ${ }^{39}$ Despite their fraudulence, these categories became the foundation for the "indirect rule" model of local government. This system was embedded in the philosophical foundations of the evolving schools of early twentieth-century imperial ethno-historical research.

From I 899 to 1906 the main proponent of indirect rule, Frederick Lugard, had been the High Commissioner of the Protectorate of Northern Nigeria. As a military man he was partial to the ordered (and authoritarian) governing system created in Nigeria's Muslim north. In I9I4 he became Governor General of a unified Nigeria and was perplexed by the plethora of governing forms that had developed under colonial rule in the south-east. He began a centralization process in I9I2 (acting as Governor of the two protectorates of Northern and Southern Nigeria) that removed European officers from the courts, gave more authority to the chiefs, and laid a foundation for corruption, extortion, and terror, all emanating from the "native courts" controlled by these chiefs. ${ }^{4}$ As noted above, "indirect rule" was the guiding principle for industrial relations in the coal industry. The colonial "warrant chiefs" (government-appointed chiefs who were given a warrant to symbolize the authority of their position) became labor recruiters and were given the power to recruit and discipline labor through their "boss boys", who brought crews of drafted young men to work. There they supervised them at work and in the labor camps, controlled by the chiefs.

In many cases the chiefs were from within the Ogaranyan class, and they relished this legitimacy conferred by the colonial state. They responded to the state's first labor demands, which were rationalized as punishment for resistance, by seizing young men and slaves. The labor needs were many: unskilled labor to develop the infrastructure, for head porterage, to clear

39. One study that follows this format is Percy Amaury Talbot, The Peoples of Southern Nigeria, 4 vols (London, i969).

40. Native courts were part of the indirect rule that was practiced throughout Nigeria. The government appointed men as chiefs and gave them the right to try certain types of cases in the districts over which they reigned. The courts included a chief, a clerk, usually a Saro or literate local, and messengers who canvassed the area delivering court warrants and arresting defendants. The system bred corruption and permitted the chiefs, clerks, and messengers to extort fines from the population, to demand women as wives, and to draft young men to work in their fields. In I9I 2 they became even more corrupt because Lugard prevented the District Officers from attending the courts. The educated elite in Lagos was especially incensed by these reforms, because Lugard refused to allow any lawyers to attend the sessions and ignored their calls to eschew "traditional" institutions that they felt represented authoritarian "traditions" and corrupt practices. Chiefs used the courts to get money, to lend money to indigent defendants, and to create near fiefdoms. The major study is Adiele Eberechukwu Afigbo, The Warrant Chiefs: Indirect Rule in Southeastern Nigeria I891-1929 (London, 1972). 
streams and bush paths, and to build roads. Government buildings and official quarters needed to be built, and the infrastructure for the coalmines and the railway constructed. One example of such a labor-recruiting chief was Chief Njemanze of Owerri. He had been a powerful slave trader, who worked with the Aro slavers, an enterprising Igbo clan who controlled slave procurement - in the area's periodic market system. ${ }^{4 \mathrm{I}}$ After the British Aro Expedition in I90 I-I 902 he switched sides: he helped guide the troops to Aro Chukwu, the Aro capital, and convinced villages not to contest the armies. ${ }^{42}$ Later on, Njemanze sent several hundred workers to Enugu, including a number of tradesmen whose mission-trained skills made them especially valuable to the railway operations. Another case is that of Eze Okoli, a famous dibia ("native" doctor) from Nnoli near Onitsha. $\mathrm{He}$ was especially helpful to the British. He embraced Christianity, took private lessons in English, and supplied troops for the Cameroon campaign in World War I. ${ }^{43}$ Okoli sent hundreds of young men to Enugu to work in the mines.

In the Udi area two prominent men, Chief Chukwuani Nwangwu of Nkanu and Chief Onyeama Onwusi of Agbaja, both Ogaranyan, shifted from being slave dealers to labor recruiters, calling up hundreds of men for forced labor and/or local slavery. Both had been prosperous slave and palm traders, and had supplied railway workers from the Agbaja and Nkanu areas of Udi. Now as chiefs, both claimed "customary" rights to conscript workers, although in reality no Ogaranyan could claim labor beyond his own household. In ignorance, colonial field officers assumed that in supplying workers they were merely exercising the same "customary" rights as a "house" head on the coast. ${ }^{44}$ The chiefs claimed the authority vested in several labor laws that allowed the state to conscript labor. These included the Masters and Servants Act, Roads and Creeks Ordinance, and the so-called House Rules Ordinance, which enabled the chiefs to conscript workers, establish courts in the labor camps, and manage the labor camps using their own paramilitary groups to keep order. ${ }^{45}$

4I. For a discussion of this sophisticated slave procurement system of the Aro see Northrup, Trade Without Rulers, ch. 5.

42. Afigbo, The Warrant Chiefs, p. 64 .

43. Amadiume, Male Danghters, Female Husbands, p. I38.

44. Coastal "houses" were commercial institutions that emerged with the slave trade and expanded with the palm oil trade. They evolved from a segmentary kin-based compound (which continued to exist in the interior) into a hierarchal "house" of slaves. The most detailed explanation is in Kenneth O. Dike, Trade and Politics in the Niger Delta, I830-I885: An Introduction to the Economic and Political History of Nigeria (Oxford, 1956).

45. This triumvirate of laws were the legal framework for Britain's forced-labor policies. For a discussion of how these three laws worked against African labor, see Brown, "We Were All Slaves", ch. 2; also Tekena N. Tamuno, The Evolution of the Nigerian State (New York, 1972). 
Chief Onyeama used his Ogwumili force, ${ }^{46}$ a private militia of "enforcers" and labor headmen, to insure that workers, once in the labor camps, complied with his regulations. Onyeama also invented an elaborate labor-recruitment system emanating from his native court. He contacted subordinate chiefs, instructing them to call up men within specific age grades, ${ }^{47}$ who then had to report to a series of transit camps where agents checked off their names on the list for their villages..$^{4} \mathrm{He}$ also used his court to enforce workplace discipline, all with the tacit approval of the political officers. Onyeama and other chiefs were allowed to make deductions from the workers' wages to cover costs of food and other, less legal, expenses. ${ }^{49}$

While the chiefs conscripted their men for the mines and other projects, they also wreaked havoc in the rural villages. Legal prohibitions notwithstanding, Amadi still enforced slavery in their villages, relying upon the fears of colonial officials that public emancipation would create social disorder. ${ }^{\circ}$ Attempts by the Amadi to change the terms of slavery to give them more control over their erstwhile workers led to a major revolt in 1920-1922, which required a military patrol for several months and resulted in the deaths of many Amadi and Obu. In addition, traditional practices in the native courts controlled by the warrant chiefs were increasingly violated. Most warrant chiefs operated with impunity, even after the uprisings during World War I, when many of them were either killed or run out of their villages. ${ }^{\mathrm{I}}$ They leveled false charges against men, collected fines, or demanded a daughter as a wife. Others became moneylenders, requiring pawns to work off the interest on usurious loans. ${ }^{52}$

46. Only anecdotal information is available about Onyeama's Ogwumili force. See Onyeama, Chief Onyeama, p. 40; Robert L. Tignor, "Colonial Chiefs in Chiefless Societies", Journal of Modern African Studies, 9 (197I), pp. 339-359, 350; Felix C. Mgboh, "The Biography of Chief Onyeama: A Research Paper Presented to the Department of History-Civics Alvan Ikoku College of Education, Owerri", June 1980 (unpublished), p. I 2.

47. Age grades were groups of men and women who were initiated into adulthood during the same year. They were formed every several years and were often named after some event. Those born around the time of the Spanish flu of i9r 9 were named "Fluenza".

48. Interview with C.O. Ude, Amokwe, Udi, 23 February 1972; interview with Chief J. Nwankwo, Eke, Udi, 7 March 1972; interviews conducted by Innocent Uzoechi, both cited in Innocent F.A. Uzoechi, "The Social and Political Impact of the Eastern Nigerian Railway on Udi Division, I9I 3-1945” (Ph.D. dissertation, Kent State University, I985), p. I 25.

49. NNAE, ONDIST I2/I/I 562, Colliery Manager to District Officer, I7 February 1920, enclosure in Acting District Officer to Resident Onitsha, I6 February 1920.

50. The British also hesitated to institute a public emancipation for fear of having to pay the compensation to slave owners that they had encountered in the West Indies. See Suzanne Miers and Richard Roberts, The End of Slavery in Africa (Madison, WI, I988).

5I. Akinjide Osuntokun, "Disaffection and Revolts in Nigeria during the First World War, I9I4-I91 8”, Canadian Journal of African Studies, 5 (1971), pp. I71-192.

52. Pawnship was a practice in which a debtor gives a relative to the creditor until the loan is repaid. The labor of the pawn did not pay off the loan principal but the loan interest. 
Despite all of these problems and signs of unrest, officials allowed the native court system to continue and consolidate. At one point they even paid Udi's two chiefs to supply targeted numbers of workers for the mines. In the slave villages in Nkanu, Amadi chiefs used the courts to extort money from their slaves, which became another contributing factor to the violent I 920 revolt. Significantly, this helped $\mathrm{Obu}$ to embrace their identity and mobilize throughout Nkanu, forming a social movement that expanded beyond the slaves to include other poor sectors of the communities. ${ }^{53}$

Despite all the problems with corruption, child stealing, extortion, and violence by the chiefs, what would finally end the warrant chieftaincy system was the 1929 uprising by thousands of Igbo, Ibibio, and Efik women who, fearing that chiefs would tax them, rose up and brought down the entire local government structure in one fell swoop. ${ }^{54}$

\section{“COME TO THE CITY AND BE FREE!”: CLERKS, RUNAWAY SLAVES, AND RURAL DISSIDENTS - ENUGU AS A CENTRE OF ANTI-CHIEF PROTEST}

The city of Enugu began as a cluster of labor camps located on land secured from a group of local men claiming to be chiefs. 55 The camps were located near the railway station and the entrance of the Udi mine, which opened in I9I5. Additional camps were set up in I917, when two new mining sites - Iva Valley and Obwetti - were opened. The pioneer settlers of the new city of Enugu were a polyglot population of European military officers, "foreigners" from Lagos, Onitsha, and Owerri, and a few "locals", including village dissidents (mostly younger men from the local surroundings) who wanted to escape the abuses of senior men and chiefs in the village.

During World War I Enugu grew rapidly into a cosmopolitan city. In relation to its surroundings, it was indeed a "foreign" town. Until the I940s, the majority of the Igbo inhabitants were either from Owerri or from Onitsha, both areas about 100 miles away from Enugu. ${ }^{56}$ After the war the rural officials noted the presence of new men who were emerging as troublesome challengers to the chiefs' control in the villages. The city had become a den of sedition, with clerks and other "foreigners" campaigning against the "traditionalism"

53. See Brown, "Testing the Boundaries".

54. The literature on this "Women's War" is quite extensive. See, for instance, Judith Van Allen, "Sitting on a Man': Colonialism and the Lost Political Institutions of Igbo Women”, Canadian Journal of African Studies, 6 (1972), pp. 165-18 I; Misty Bastian, "Vultures of the Marketplace: Southeastern Nigerian Women and Discourses of the Ogu Umunwaanyi (Women's War) of 1929", in Jean Allman, Susan Geiger, and Nakanyike Musisi (eds), Women in African Colonial History (Bloomington, IN, 2002), pp. 260-28 I.

55. For most of the colonial period the people of Udi initiated multiple court proceedings to get this transaction invalidated.

56. Calculations included in NNAE, Paul E.H. Hair, "Enugu” (n.d. mimeograph). 
of the chiefs. The young coalminers repeated these critiques, which fit quite comfortably with their own disagreements with the elderly chiefs and senior men in their villages. In the villages the "coal men" were a proud, contentious group that articulated the political perspective of young and politically marginal men. This was the inevitable consequence of the industry's existence amid the contradictions of a bankrupt rural policy and the corrupt hierarchies it created. The miners assumed an identity that opposed exploitative chiefs, thereby undermining local government. One pensioner proudly noted: "The miners were most modern and powerful. Because they were always after democracy. And they don't allow the chief by opposing him to harass his people. And they always succeeded in opposing him." 57

By the end of World War I Enugu had all the trappings of a fully segregated colonial town: a "native" and European area, separated by the customary "neutral zone"; ${ }^{8}$ several trading firms; mission schools; labor camps for the railway and mines; a police force; prisons; and other government agencies. ${ }^{59}$ Like most colonial cities, residential segregation - the European reservation was an important representation of imperial power and a showcase for the "superiority" of European civilization. This representation of "white" authority was but a façade to the reality of fragile political control in a territory that far exceeded the scope of British military resources. Such representations of the dichotomy between European/African, colonizer/subject, and black/ white were especially important in spaces where Africans and Europeans were in daily contact - the city and the colonial workplace. ${ }^{60}$

By 1927 the city had grown to I0,000 inhabitants, 7,000 of whom worked in various government departments. ${ }^{61}$ In 1929 the city changed qualitatively, when Enugu became the administrative capital of south-eastern Nigeria. The variety of jobs in government gave Enugu's African population a class complexity uncommon in most Nigerian cities. Most workers were accustomed to negotiating with political officials during disputes and had begun to develop a set of expectations for their treatment by the state. The industrial component of the city gave this government town its "edge", with most workers looking to the coalminers as leaders in labor conflicts. Added to

57. Interview conducted in English with Augustine Ude, Umuagua, Udi, 5 August 1975. Ude began work as a messenger in the colliery in I919 when only ten years old.

58. Philip D. Curtin, "Medical Knowledge and Urban Planning in Tropical Africa", The American Historical Review, 90 (1985), pp. 594-613.

59. NNAE, Hair, "Enugu", pp. I62-I63.

60. On the spatialized representation of colonial relations, see the instructions Governor General Lugard sent to his officials: Frederick Lugard, The Political Memoranda: Revision of Instructions to Political Officers on Subjects Chiefly Political and Administrative, 19I3-I9I8 (London, 1970, 3 rd edn); also see Maynard W. Swanson, "The Sanitation Syndrome: Bubonic Plague and Urban Native Policy in the Cape Colony, 1900-1909", Journal of African History, I8 (1977), pp. 387-410; and Curtin, "Medical Knowledge and Urban Planning in Tropical Africa".

6r. NNAE, Hair, "Enugu”. 
the thousands of coalminers were several hundred clerks employed through the government agencies from throughout the coastal regions of the colony. They and the artisans saw themselves as part of an enlightened group with skills that were valuable, if not indispensable, for the smooth operation of the industry and the colonial state. As "foreigners" they had an awareness of colonial society that came from their earlier exposure to mission education and colonial administration.

The clerks were loyal members of the colonial civil service, but they were critical of the racial hierarchies of colonial society, which they considered to be quite "un-British". When the white civil service struck for more wages after the war, they launched their own protest, adding a demand for the end of job discrimination. They were enemies of "traditionalism", and most especially of the rural chiefs, and contributed to a general environment of resistance and protest characteristic of urban life. They were just the type of African that officials viewed with foreboding - "detribalized" Africans free of the moderating influence and control of their chiefs. But they played a contradictory role in the city. They formed urban associations that became an important pillar of urban order for a beleaguered colonial administration, reliant on "native" allies, both rural and urban. In return for this assistance they expected to receive more political authority. This, the state was reluctant to grant.

The jobs in government agencies also meant that male workers could now imitate the "big compound" of the Ogaranyan, with many wives, children, and dependents. In fact, officials found that government workers' households were two to three times larger than those of other workers. This status model destroyed all British attempts to regulate housing occupancy as a way of controlling the city. One worker's experience expressed these new possibilities. He was from Udi and chose to marry six wives. He proudly expressed his successful attainment of rural elite masculinity emulating the Ogaranyan:

The development of [the] coal industry did a lot to my village. But for coal industry civilization would have not reached us as early as it had reached us. The coal industry initiated me into Ozo title. I am Ozo Samuel N. Onoh. I was able to train up my children, build good houses. We contributed money and build schools and churches. ${ }^{62}$

The authorities had built the colonial state on a foundation of rural authoritarianism, creating chiefs where none had existed before, and giving them powers far beyond those of any group in Igbo village government. This rural transformation made the city into a refuge for rural dissidents,

62. Interview conducted in English with Samuel N. Onoh, Ngwo-Etiti, Nigeria, 9 August 1975. Onoh began work in I9Is as a tubman and worked up through the ranks until he became an underground foreman after World War II. 
some from the local areas, and others from more distant "foreign" communities. A few were women who were unhappy with their marriages or marriage prospects, many more were young men fleeing the exactions of autocratic chiefs and slaves deserting their masters. In the city, these rural dissidents joined with the clerks, and participated in a cultural and political struggle over the nature of work and urban life. For the men from local areas minework rotated with farming, and their commitment to the job fluctuated with the farming seasons. For "foreigners", the distance from home was so great that they were forced to become more acclimatized to life and work in the city. However, they, like most migrants to African cities, nonetheless considered their natal village to be their home. ${ }^{63}$

Many of the young men refused to work regularly, rebuffed missionary attempts at conversion, and clustered in slum settlements that defied administrative control. In so doing, Africans resisted colonialist attempts to instill industrial time into their culture, to restrict access to space through the marketplace, and to restructure their households into nuclear families as against polygynous rural norms.

Both the colliery and the city emerged under the watchful eye of the Governor General Frederick Lugard. Lugard's personal interest in the city and the industry arose from his belief that while wage labor was of educative value for African labor, Africans should remain socially rooted in their rural communities away from the "dangerous" temptations of urban life. Lugard found that it was very difficult to prevent a permanent urban-based working class from developing. ${ }^{64}$ Despite his efforts to keep the numbers of urban Africans to a bare minimum, his rural policies pushed them into the city.

To Lugard's dismay, the clerks and artisans were from the Lagos elite that had mobilized so vigorously against the conquest and the discrimination in government employment. Furthermore they had declared war on Lugard, whom they attacked in their press as the archetypal arrogant imperialist. ${ }^{65}$ Lugard hated the Westernized elite for being "Africans out of place", far too arrogant for "natives". To him, they were "natives", and no amount of English competence, Western clothes, and sophisticated literacy would make them equal to the "real" British. Similarly he hated the artisans

63. The natal village looms large in the identities of most African urban dwellers, historically as well as today. They return to the village for important meetings, and migrants build a house there even if they spend their entire life in the city. During the colonial period women returned to give birth, and everyone is buried there. Even today, when someone dies abroad their family or migrant community will collect money to repatriate the body.

64. Frederick Cooper, "Urban Space, Industrial Time, and Wage Labor in Africa", in idem (ed.), The Struggle for the City: Migrant Labor, Capital, and the State in Urban Africa (Beverly Hills, CA, I983), pp. 7-50.

65. Fred I.A. Omu, Press and Politics in Nigeria I880-1937 (Atlantic Highlands, NJ, I978). 
(i.e. skilled African workers) who, like the clerks, became a thorn in his side by organizing protests against racial discrimination and poor salaries. ${ }^{66}$ As Enugu grew at an extraordinary pace, it created a receptive context for these new traditions of resistance. Thus, while Lugard was busily trying to stabilize rural Igboland around colonial chiefs, the clerks and coalminers were making the city a center of dissent that gave voice to the complaints of the young men who were the chiefs' victims.

The first contingent of railway clerks and artisans in Enugu originated from mid-nineteenth century Lagos and had gradually dispersed throughout the coast, settling in several cities in eastern Nigeria - Calabar, Onitsha, Owerri, and Enugu. These were a transnational group of men from communities in Britain's black Atlantic empire: a sprinkling of West Indians, Creoles/Saro from Sierra Leone, returnees from Brazil (called Amaro), Yoruba men from Lagos, and Igbos from the more "civilized" areas on the coast and the cosmopolitan market town of Onitsha on the Niger River. They had a profound belief in personal and group improvement, independence, "progress", self-reliance, "civilization", and the supremacy of British culture as the pinnacle of civilization. When they arrived at the coalmines early in World War I, the city of Enugu did not formally exist. They relished the opportunity to "tame" the countryside, to carve this modern industry out of the forest; in this way they fulfilled an aspect of Victorian manhood the mastery over the self and the environment. In the r 930 of officials noted that these men saw themselves as "pioneers", who had carved the mines and city out of the "bush", at a time when the locals were still "cannibals" ${ }^{67}$

During the war the clerks organized new home-town ("tribal") associations to provide mutual aid, assist in urban socialization, and finance development projects in the home villages, which heightened their prestige in rural politics while they were away. The first urban Nzuko or "meetings" were formed in igis by Westernized men from Owerri. The form soon spread to other groups of "foreign" residents of Enugu. ${ }^{68}$ Nzuko also allowed the "respectable" members of migrant communities to assist in controlling and socializing the young. ${ }^{69}$

66. Arnold Hughes and Robin Cohen, "An Emerging Nigerian Working Class: The Lagos Experience, I897-1939", in Peter Gutkind, Robin Cohen, and Jean Copans (eds), African Labor History (Beverley Hills, CA, 1978).

67. University of Liverpool, Paul E. Hair Collection, Charles H. Croasdale, "Report on the Enugu Colliery, 1938", n.d., pp. 40-4I.

68. The "locals" from the surrounding areas, however, continued to participate in rural associations where, as coalminers, they could leverage their wages and prestige as "modern" men to secure authority in the village. The literate clerks were the associations' leaders, but membership was multi-class, being based on the natal village.

69. For a discussion of this, see Brown, "We Were All Slaves", pp. I05-106. For a discussion of the contradictions between "sons abroad" and the village leaders, see Dmitri van den Bersselaar, 
Nzuko represented a new type of men, migrant workers, those whose absence from the village prohibited their daily involvement in rural politics but whose missionary education, industrial training, or wage labor made them intermediaries between the village and the new economy and political apparatus. ${ }^{70}$ As an institution, the Nzuko allowed urban and wage-earning men to exhibit collectively some of the characteristics of "big men". They redirected financial resources with largesse to "bring the village up". This element of helping the collective was an important demonstration of a wealthy man's moral power. The Owerri men were the first to form Nzuko, which enabled them to support "modern" projects, such as schools, maternity clinics, and road construction. At the same time, their claims of "modernity" introduced new criteria for male maturity. This enabled young men to challenge the power of senior men in the village councils.

Nzuko meetings opened an important social environment in which both elite and working-class masculinity could be performed, ${ }^{7 \mathrm{I}}$ especially by the clerks, who avidly demonstrated their command of Western meeting protocols. While the clerks were especially keen to laud their sophistication over the illiterate workers, the postwar economic conditions were encouraging a coalition of these different groups. Although class distance had initially been of crucial importance to the self-identity of the proud clerks, discriminatory wages and residential segregation blurred these divisions. Wartime inflation further depressed their discriminatory wages, putting the "respectable" lifestyle that so defined their identity beyond their reach. This forced them to live in the same squalor as the unskilled urban workers, their inferiors.

While they felt superior to the manual workers, the literate Nzuko leaders nonetheless opened an avenue for the politicization of these illiterate men. This enabled the elites' values, political expectations, and gender ideologies to filter into the discourse of illiterate workers. Importantly, their meetings became a context in which clerks and artisans demonstrated new ideas about the expectations, role, and responsibilities of "modern" African men. Their relationship with colonial officials was ambivalent: while they saw themselves as assisting in preserving urban order, a function appreciated by the state, they became an organizational platform through which "Westernized" Africans could leverage their power in the transformation of

\footnotetext{
"Imagining Home: Migration and the Igbo Village in Colonial Nigeria", Journal of African History, 46 (2005), pp. 5I-73.

70. See Audrey C. Smock and David R. Smock, "Ethnicity and Attitudes Toward Development in Eastern Nigeria", The Journal of Developing Areas, 3 (1969), pp. 499-5 I 2; Immanuel Wallerstein, "Voluntary Associations", in James S. Coleman and Carl Rosberg (eds), Political Parties and National Integration in Tropical Africa (Berkeley, CA, 1964), pp. 31 8-339.

7I. The performative aspect of masculinity is discussed in Lindsay and Miescher, "Introduction", in idem, Men and Masculinities, pp. I-9.
} 
the colony. In fact, during World War II they coalesced into Nigeria's first nationalist party. In the meantime, Enugu's unskilled miners would "borrow" the Nzuko form to create their first workers' organizations.

\section{THE EROSION OF VILLAGE-BASED IDENTITY: UDI'S “NEW" MINERS ATTACK “NATIVE” SUPERVISORS}

The first industrial strikes (I917-1919) were led by artisans and clerical workers seconded from the railway. Although both looked down on the unskilled workers, they nonetheless influenced the forms of protest that would later be adopted by the more "local" underground laborers. In i 9 I 9 the locals did not participate in a series of strikes related to the inflationary spiral of the war and the consequent postwar unrest among both African and European civil servants. ${ }^{72}$ The center of the strikes was in Lagos, where in 191 8 Africans in the Nigerian Civil Service Union petitioned for salary increases and protested against discriminatory treatment - though to no avail. ${ }^{73}$ In any case, these early industrial strikes were led by the "foreign" artisans and organized by the industrial derivatives of the home-town unions, the Nzuko Ifunyana. The strikes were caused by a number of factors: food shortages, payment in unpopular paper money, and the harsh measures used by "native" foremen to control the workers. The new industrial Nzuko synthesized Western voluntary associational forms with Igbo principles of corporate affiliation.

This formation of an autonomous workers' association, free from the interference of the chiefs or their "boss boys", was one indicator of the influence of seasoned workers and clerks on the less experienced miners. The postwar agitation expressed personal and collective definitions of "just" and "unjust" compensation and treatment for employees within an evolving set of expectations of the colonial state. The forms of protest reflected differential employment patterns, residential options, and variations in the regional significance of and familiarity with wage labor. These ideas about appropriate treatment and compensation were first expressed by urbanized "foreign" clerical, artisan, and skilled underground workers, but by the mid-r920s this protest culture had been rapidly embraced by local men, despite their continued affiliation with

72. The Nigerian staff's key demand was for the end of job discrimination; Wogu Ananaba, The Trade Union Movement in Nigeria (New York, 1969), p. I I.

73. There were a whole series of discriminatory practices that elicited African protest. Africans had not received a wage increase since 1906 , and there was a ceiling of $£_{3} 00$ per year on African employees, regardless of qualification and job. Africans did not qualify for a pension until they had completed thirty-seven years of service. Most died before they could receive it. They also complained that the use of the word "native" when referring to African medical officers was derogatory. See Akinjide Osuntokun, Nigeria in the First World War (London, 1979), pp. 296-297; Matthew A. Tokunboh, Labour Movement in Nigeria: Past and Present (Lagos, 1985), p. 22. 
collaborative leaders in their village. This model of protest was an important dimension of the response of African workers to colonial capitalism.

Of the three strikes after World War I, only the first, in 1920, was led by "foreign" workers. At this time most "local" workers followed their normal pattern of protest and chose desertion. However, although the first strike was unsuccessful in securing the restoration of a rate cut made at the beginning of the recession that started in 1920 , it demonstrated the forms of protest appropriate to the colonial workplace. ${ }^{74}$ There is little archival documentation about the strike. We know only that skilled underground workers or hewers, "foreigners" from Awka, Owerri, and Onitsha town, participated in the strike. The management rejected the demands, dismissed the protesting miners and station magistrate, and four policemen chased them into the woods. ${ }^{75}$ One of the leaders singled out by management, European staff, and African headmen was Edward Okafor of Umouji (Onitsha division). He was dismissed for insubordination and blacklisted in all other government departments. When the other hewers threatened another strike that April, the management decided to hire only Agbaja men, who they assumed would be less activist. ${ }^{76}$

In following this policy the colliery manager acceded to a request by representatives of the Agbaja clan group, who argued that, since the mines were on their lands, they should be given preference in all hiring. Within five years the Agbaja constituted the majority of the underground workforce, both skilled and unskilled, and the "foreigners" held only the clerical and administrative positions. ${ }^{77}$

This expectation of Agbaja docility proved short-lived. In the aftermath of the British General Strike of 1926, the Agbaja day laborers walked off their jobs in July, demanding a I-penny increase. This would have raised their paltry wages to I shilling and 3 pence per day. Agbaja men had held a series of underground support jobs, often called "dead work", that supported the "pit boys" (hewers). ${ }^{78}$ They were all on daily wages rather than the hewers' tonnage rates and could therefore not increase their incomes by working harder. At the same time, the payment of day wages to

74. Little remains in the archives about these events, and only tangentially relevant documents exist in colonial records. See, for instance, NNAE, ONDIST I 2/I/I 562 , Resident to Colliery Manager, I I March I925; Colliery Manager to Resident, I 2 March I925.

75. NNAE, NRUCAR 1924/25; Agwu Akpala, "The Background of the Enugu Colliery Shooting Incident in 1949", Journal of the Historical Society of Nigeria, 3 (1965), pp. 335-363, 347. 76. For a detailed account of this first rash of strikes after World War I, see Brown, "We Were All Slaves", ch. 4 .

77. NNAE, File no. PA 260, Resident to Executive Enugu, "Labour Force Colliery Department, Towns of Origin", 28 March 1925 (destroyed), as cited in Akpala, "The Background to the Enugu Colliery Shooting Incident", p. 339.

78. For a discussion of the use of childlike terms to describe adult men see Brown, "A 'Man' in the Village". 
such a broad spectrum of the underground workforce encouraged solidarity and collective action. As increased effort had no impact on income, securing higher wage rates was the only way that these workers could increase their wages. Clearly, the "backward" Agbajas had learned from the "foreigners" and from their own experience in the mines. They no longer deserted, as they had in the past, but recognized the power of stopping production to underscore their demands.

A second series of strikes was related to rampant corruption and the chiefs' agents in the mines. The management structure and system of industrial relations at Enugu was an industrial application of "indirect rule": work in the mines exposed the men to a complex system of extortion and corruption, a fact that was understood by management but, as long as it secured industrial discipline, was of little concern. In fact abusive practices in the system of labor recruitment and control at the colliery were just an industrial expression of the problems inherent in the indirect-rule system at large. African intermediaries were given many managerial functions, with little European supervision. The chiefs' "boss boys" and various other "native" supervisors handled daily colliery operations. With the general manager insulated from the daily supervision of the men, a culture of predation emerged in which both Africans and Europeans used corruption, extortion, and physical violence to push the workers to produce.

Of all the supervisory staff, the men complained most bitterly about the exploitation of the "boss boys". From the position of the worker, the "boss boy" was the most powerful "native" supervisor in the mine. He decided who worked and where they would work. He was responsible for discipline, which he could enforce outside the workplace in the villages with the help of the chief and native courts. His power over individual men, exercised through physical violence, was ominous and arbitrary. Ultimately it was the "boss boy" who had the power in production and control over the hewers' wage-earning capacity.

In September 1929 the "local" hewers walked out of the mines to protest the illegal deductions from their pay by the "local" "boss boys". This was the most significant strike, from the perspective of regional and "local" identity, as it suggested that clan/village affiliation was not as secure a basis for industrial peace as in the past. The Agbaja workers launched a full frontal attack against the men who recruited and victimized them. Under the industrial application of "indirect rule", men like the "boss boys" could extort money from the workers without any managerial oversight. If a miner refused to pay a bribe, the "boss boy" retaliated by placing him on a difficult workface where he would be unable to hew large amounts of coal.

The "boss boys" and headmen selected their work crews daily from the men in the labor camps, and they alone knew who was in their crew. ${ }^{79}$ 
In some cases they received the wages for their entire work crew. ${ }^{80}$ The consequences were predictable, as one miner noted:

The Colliery was paying its workers by the month. The boss-boys and headmen exploited this and often arranged to dismiss laborers a few days before pay day and take on other men. The headmen then drew the pay for the whole month and kept for themselves that of the dismissed men. The paying officer could not check this because he did not know the laborers individually. ${ }^{81}$

Alternatively, the "boss boys" could arrange with the European overmen to have the miners fired. Neglect by management was not coincidental, but expressed a generalized assumption that the "boss boys", as men from the village, should be given carte blanche in the mines.

Similar accusations were raised against the interpreters, again local men who were intermediaries between their crews and European overmen. One Agbaja tubman complained:

Interpreters caused the sudden dismissal of many workers. They really were very wicked to workers. When they find one resting in the working place and if such a one refuses to bribe him he would accuse such a one [of] sleeping on duty or accuse him of one serious offense which will lead to his dismissal. They always report them to the Europeans who dismissed such a one. ${ }^{82}$

Both "boss boys" and interpreters were of inestimable value to management, especially when they functioned as informers on the miners. They attended workers' meetings and informed on the ringleaders, who were subsequently dismissed. To counter this, the workers attempted to use "traditional" methods of securing solidarity and began using oath-taking at their secret meetings. ${ }^{{ }_{3}}$ But as the colliery workers became more conscious and organized, curtailment of these corrupt practices was considered a priority, with claims of clan affinity (and corresponding obedience) losing their power.

\section{CONCLUSION}

This article has traced the contours of the challenges confronting a new working class as it experimented with unfamiliar forms of affiliation, trust, and association with people with whom it shared new, industrial experiences. This has included investigation into the many ways that local men maneuvered against the authoritarian control of chiefs, forced labor, and workplace exploitation by "native" and expatriate staff. The management and the collaborating rural leaders wanted to continue to use village loyalty as an

80. NNAE, OP 45/192 I, Railway Construction: Recruitment of Labour and Arrangements for Control Thereof, cited in Akpala, "Enugu Colliery Shooting Incident”, p. 34I.

8 I. Interview conducted in English with Chief Thomas Ozobu, Imezi Owa, Udi, 2 I June 1975.

82. Interview conducted in English with Anieke Chiegwu, Umuagba Owa Imezi, 7 July i975.

83. Interview conducted in English with Bennett U. Anyasado, Mbieri, Owerri, 23 July 1975. 
enduring basis for industrial organization and worker control. But as early as I9I9 the "pull" and legitimacy of the village governing system was already under strain. A political official complained about the problems "colliery boys" caused for the chiefs in the village-groups most heavily involved in the industry:

This system of boys [in Enugu-Ngwo, Abor and surrounding towns] living in their town and working at the mines is not one I prefer. The trouble is that the colliery boys living in the towns will not obey the chiefs who complain to the Political Officer that these boys are loafing in the towns and will not obey them. ${ }^{84}$

Too disruptive to live in the village, too threatening to the tenuous urban order to live in the city, the mineworkers challenged all imperial fantasies and stereotypes about the nature of African workers. Their very existence as workers contradicted the ideological assumptions officials had about African society and the patterns of authoritarian rule that officials tried to insinuate into village politics. The miners' insistence on "democracy" challenged what colonial authorities assumed was an endemic authoritarianism rooted in African society.

Initially most local workers were quite unfamiliar with the capitalist workplace. But the "foreign" artisans - the skilled African workers from other cities and often with a remarkably cosmopolitan background - exhibited a working-class identity that had been encouraged by their education in missionrun technical schools. They were rational, independent, self-improving men, whose pride in performing a skilled task resonated with some aspects of local Igbo masculinity, facilitating a synthesis of gender ideologies. These "foreigners" demonstrated the effective forms of worker protest and organized the industry's first strikes during World War I.

While "white" bosses used race, class, and gender ideologies to construct repressive systems of labor control in the new colonial workplace, African miners countered by creating eclectic models of masculine prestige, which they demonstrated in the villages. They became providers of "development" and village uplift, thereby using industrial jobs to achieve the valued accomplishments of men in Igbo culture. In this respect they invented forms of self-representation that merged local and foreign gender ideologies arising from work, rural culture, and the influence of the more established industrial workers who came at the beginning of coalmining in Enugu.

As the colliery and the city entered the tumultuous decade of the I930s, the hold of clan identity on the workers was clearly losing currency. Many young men saw themselves as a different breed. As noted above, even as early as the first years of World War I, District Officers complained that

84. The National Archives, Kew, Public Records Office, CO 657/4, Nigerian Railways and Udi Coal Mines Administrative Report, 1919, E.M. Bland, General Manager, p. 96, as cited in Uzoechi, "Eastern Nigerian Railway", p. 208. By "towns" the author does not refer to Enugu but to rural settlements. 
young men had already begun to challenge rural leaders, who they felt were so ignorant and so archaic that they could not really understand the industry. For those in the industry, the conflicts they encountered with their clan mates in the workplace pushed them to question the ability and legitimacy of senior village leaders and those wealthy men, Ogaranyan, who tried to advise them on the problems they encountered in the workplace. Rather, they trusted the workplace commonalities they had with men from "foreign" areas of Igboland, and drew upon their expertise in crafting movements of solidarity and handling problems with management. The experience of working in this industry and living in Enugu led them to abandon rural patterns of affiliation and political leadership based on kinship, age, and wealth, and encouraged them to join in solidarity with co-workers and leaders from areas that had been considered foreign or even hostile before.

This history of labor's struggles during the first few decades suggests that by assuming the identity of "industrial workers" Udi men were able to reconstruct themselves as "coalmen", men who both ran a crucial industry and were impressive promoters of modernization - both social and political. The mines gave them an opportunity to celebrate a skill, hidden in the darkness of the mines, and to confront this dangerous and mystical workplace with the courage and self-confidence that few other workers could claim. In this respect Igbo notions of male "bravery" and "commitment" merged with workplace identities in the mines. 